\title{
CAN DIGGER BLADES WEAR AFFECT THE QUALITY OF PEANUT DIGGING?
}

\author{
Adão Felipe dos Santos*1 (1D), Luan Pereira de Oliveira ${ }^{2}$, Bruno Rocca de Oliveira ${ }^{2}$ (D), Antonio Tassio Santana Ormond ${ }^{3}$
} \& Rouverson Pereira da Silva ${ }^{2}$

1 - Federal University of Lavras

2 - São Paulo State University

3 - Minas Gerais State University

\section{Keywords:}

Worn blades

Peanut losses

Profitability

Shift harvest

\begin{abstract}
Brazilian peanut harvests have been fully mechanized and are divided into two operations, namely digging and gathering. In both operations, losses are observed, and it is essential to avoid losses to maintain adequate machine maintenance. In this study, we aimed to quantify the interference of the harvesting period (morning, afternoon, and night) and wear of the diggerinverter mechanism (blades) on the loss indexes during the dig operation. The experiment was conducted in a commercial field using worn and new blades to dig peanuts at three different periods of the day. Losses were quantified by measuring data at 20 points, which were separated by $20 \mathrm{~m}$ for each treatment. The shift work did not interfere with peanut losses. However, the blade condition exhibited a strong influence on increasing the losses. Peanut growers can increase profits by up to $22 \%$ by reducing digging losses solely by periodically changing blades.
\end{abstract}

\section{Palavras-chave:}

Facas desgastadas

Perdas de amendoim

Lucratividade

Colheita em turnos
O DESGASTE DAS FACAS DO ARRANCADOR PODE AFETAR A QUALIDADE DO ARRANQUIO DE AMENDOIM?

\section{RESUMO}

A colheita do amendoim brasileiro está totalmente mecanizada e é dividida em duas operações: escavação e recolhimento. Em ambas as operações são constatadas perdas, para evitar perdas é essencial manter uma manutenção adequada das máquinas. Este trabalho teve como objetivo quantificar a interferência do período de colheita (manhã, tarde e noite) e o desgaste do mecanismo do arrancador-invertedor (facas) nos índices de perdas durante a operação de arranquio. $\mathrm{O}$ experimento foi realizado em um campo comercial usando lâminas novas e usadas para cavar amendoins em três períodos diferentes do dia. As perdas foram quantificadas por meio da coleta de 20 pontos separados por $20 \mathrm{~m}$ para cada tratamento. Os turnos de trabalho não interferiram nas perdas do amendoim, mas o estado das facas teve forte influência no aumento das perdas. Os produtores de amendoim podem aumentar o lucro em até $22 \%$ devido à redução das perdas na escavação, apenas trocando as lâminas. 


\section{INTRODUCTION}

Peanut (Arachis hypogaea L.) has great economic importance in the global agricultural scene. Specifically, China, India, Nigeria, and the United States are the largest producers (USDA, 2018) of peanuts in the world. In South America, Argentina and Brazil are the highest producers of peanuts. In the crop season for 2017/2018, 501.8 thousand tons of peanuts were produced in Brazil, with an average yield of $3,679 \mathrm{~kg} \mathrm{ha}^{-1}$, and thereby exhibiting an increase of $59.4 \%$ when compared to the harvest of 2012/2013 (CONAB, 2013; CONAB, 2018). This increase in peanut production was because of many technological advances, but primarily owing to the advances in mechanization of peanut crops (SILVA et al., 2019), especially in São Paulo State, which is the largest producer in Brazil. Undoubtedly, the challenge for using mechanization at any stage of the agricultural process involves adapting the harvesting method to reduce damage or losses in the pods during harvest.

The peanut dig operation is performed using a digger-shaker-inverter, which usually has twin blades that penetrate the soil and cut the taproot of two plant rows. The plants are then lifted into a shaking conveyor, which is powered by a tractor power takeoff (PTO). As the plants pass and leave the conveyor, they are inverted and combined in a single windrow. During this process, losses can occur, such as pods can stay inside the soil (invisible losses) or detach and fall in the soil when the plants pass through the conveyor (visible losses). However, losses can be minimized if the digger-shaker-inverter maintenance is conducted periodically. The maintenance should include exchanging of the blades that cut the taproot of the crop (BRAGACHINI; PEIRETTI, 2008).

However, the direct contact between the blades and soil can accelerate the abrasive wear process. This process occurs when blades contact with soil particles, which in turn begin to grind the tool, and thereby lead to loss in mass via the applied movement (BINDER et al., 2017). In agriculture, the effect of this interaction (soil $\times$ blades) has been reported. Specifically, it has been observed in soil tillage operations, where blade geometry, soil type, cutting speed, cutting angle, and cutting depth contribute to machine performance (ROSA;
WULFSOHN, 1999; MOUAZEN; NEMENYI, 1999). However, there is a paucity of studies that analyzed the influence of blade wear at harvest, especially in peanuts, which exhibit growth development under the soil. This is an important issue because growers should know the effect of blades on the digging process and their influence on profit.

Based on the assumption that the wear of the digger-shaker-inverter blades can potentially influence losses in peanut harvest, the purpose of this study was to evaluate the effect of wear of the digging-shaker-inverter mechanism, at different times of the day (morning, afternoon, and night), on the visible and invisible losses in mechanized peanut digging.

\section{MATERIAL AND METHODS}

\section{Study site and machines used}

The experiment was conducted during the 2016/17 Brazilian crop season in a commercial area of 25 ha near the coordinates corresponding to $21^{\circ} 11^{\prime} \mathrm{S}$ and $48^{\circ} 12^{\prime} \mathrm{W}$, with an average elevation of $492 \mathrm{~m}$. The soil of the area was classified as RED LATOSSOIL with a clay texture (42\% clay, $20 \%$ silt, and 37\% sand) (EMBRAPA, 2013). According to the classification provided by Peel et al. (2007), the climate of the area is classified as Aw tropical. The area was sown under conventional soil tillage with the Runner peanut variety IAC 886. Furthermore, the spacing between the rows was $0.90 \mathrm{~m}$ with a sowing density of 21 seeds $\mathrm{m}^{-1}$ and an average yield of $3200 \mathrm{~kg} \mathrm{ha}^{-1}$.

Peanut was dug 120 days after sowing using an AIA-Santal II $(2 \times 1)$ digging-shaker-inverter, which operated at an average depth of $15 \mathrm{~cm}$ and was drawn by a model tractor BM 110 (AGCO) with a rated power of $80.96 \mathrm{~kW}$. The mechanized set moved at an average speed of $4.5 \mathrm{~km} \mathrm{~h}^{-1}$ at an engine speed of $1600 \mathrm{rpm}$, which in turn resulted in a PTO speed of $350 \mathrm{rpm}$ as per the manufacturer's recommendation. The water content in the soil was determined via a time-domain reflectometer probe (TDR). The operation was conducted when the pods exhibited an average of $73 \%$ maturation. The maturation was determined by using the methodology proposed by Williams and Drexler (1981).

\footnotetext{
Abbreviations used: ANOVA (analysis of variance); IDL (invisible digging losses); PTO (power takeoff); TDL (total digging losses); TDR (timedomain reflectometer); VDL (visible digging losses).
} 


\section{CAN DIGGER BLADES WEAR AFFECT THE QUALITY OF PEANUT DIGGING?}

\section{Description of treatments}

The treatments were set-up in a band design with 20 replicates. The treatment consisted of two digger blades: new blades ( $0 \mathrm{~h}$ of use) and used blades ( $150 \mathrm{~h}$ of use), which are denoted as F1 and F2, respectively. Three shifts (morning, afternoon, and night) denoted by $\mathrm{T} 1, \mathrm{~T} 2$, and $\mathrm{T} 3$ corresponded to the morning period from 8 am to $12 \mathrm{pm}$, afternoon period from $2 \mathrm{pm}$ to $5 \mathrm{pm}$, and night period from 6 $\mathrm{pm}$ to $9 \mathrm{pm}$, respectively. Data on peanut digging losses (visible, invisible, and total) were collected after the mechanized set operation was completed.

Blades with $150 \mathrm{~h}$ of use were selected, because of the damage caused to peanut plants during the digging operation in previous areas and the change in their shape when compared to that of new blades (Figure 1a). To characterize the status of each blade, the length and thickness were measured at several points on each blade (Figure 1b) before commencing the digging operation. The measurements were performed using a digital caliper and are presented in Table 1.

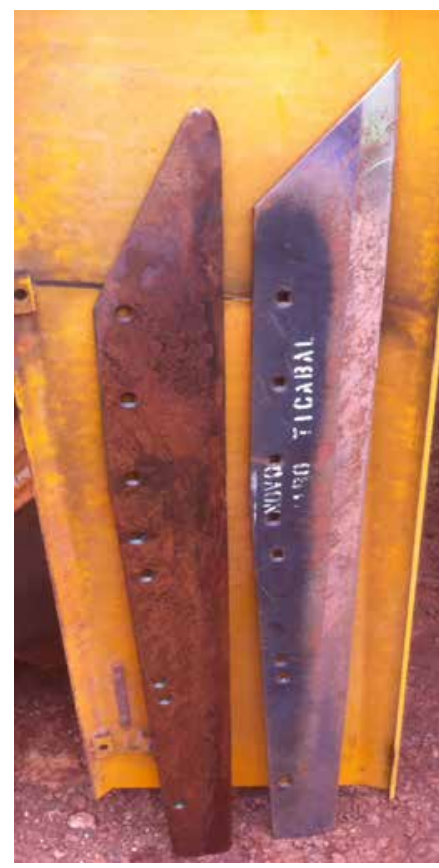

(a)

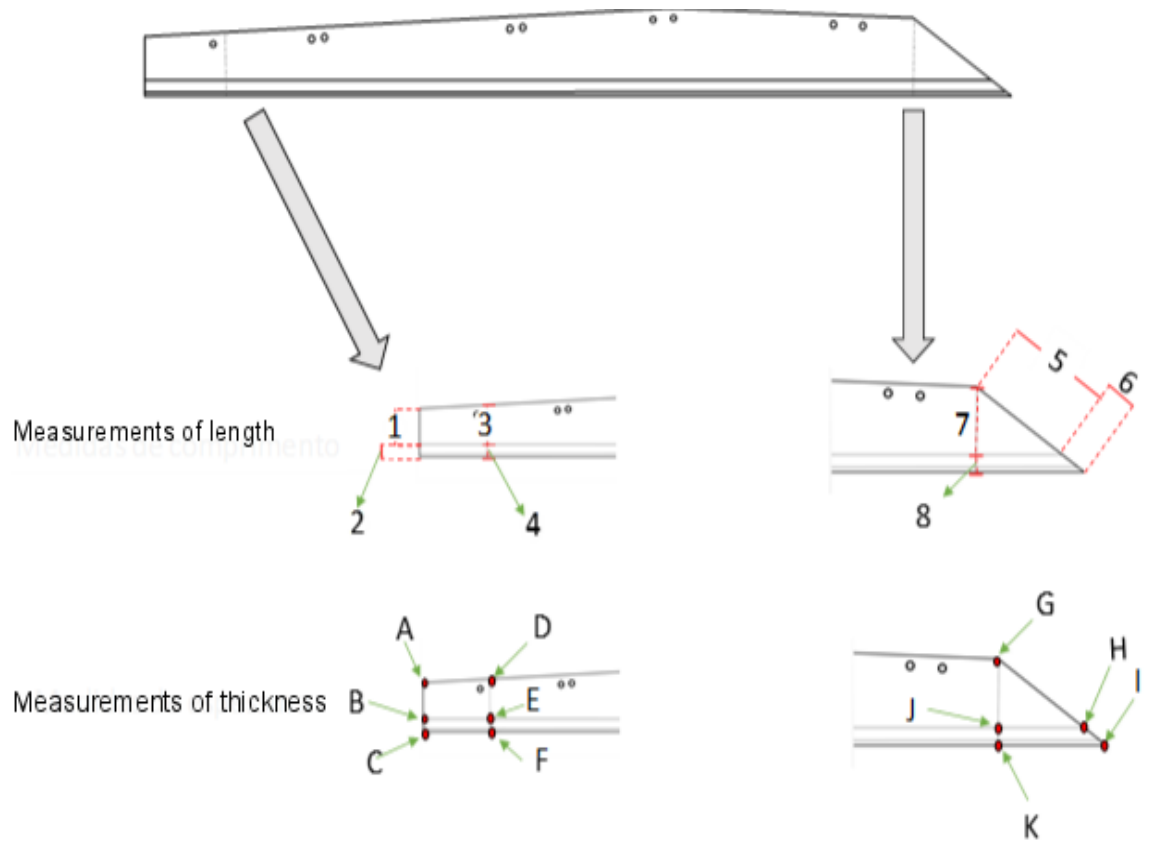

(b)

Figure 1. Blades used to conduct the experiment wherein the new blade is on the right side and used blade is on the left side (a). Description and locations of length and thickness measurements, which are used to characterize the peanut digger blades (b)

Table 1. Initial thickness and length measurements used for characterizing each blade (left and right) used in the experiment

\begin{tabular}{|c|c|c|c|c|c|c|c|c|c|}
\hline \multirow{2}{*}{$\begin{array}{c}\text { Thickness } \\
\text { (mm) }\end{array}$} & \multicolumn{2}{|c|}{ Left } & \multicolumn{2}{|c|}{ Right } & \multirow{2}{*}{$\begin{array}{l}\text { Length } \\
\text { (cm) }\end{array}$} & \multicolumn{2}{|c|}{ Left } & \multicolumn{2}{|c|}{ Right } \\
\hline & New & Used & New & Used & & New & Used & New & Used \\
\hline $\mathbf{A}$ & 9.31 & 8.78 & 9.31 & 9.26 & 1 & 4.80 & 4.00 & 5.90 & 4.20 \\
\hline B & 9.39 & 8.50 & 9.66 & 9.01 & 2 & 3.90 & 3.80 & 3.80 & 3.30 \\
\hline $\mathrm{C}$ & 1.67 & 2.93 & 2.82 & 4.01 & 3 & 5.80 & 5.50 & 6.00 & 5.40 \\
\hline D & 9.66 & 9.14 & 9.20 & 9.49 & 4 & 3.90 & 3.30 & 3.80 & 3.60 \\
\hline $\mathbf{E}$ & 9.44 & 9.35 & 9.06 & 9.69 & 5 & 13.80 & 21.70 & 14.30 & 19.80 \\
\hline $\mathbf{F}$ & 2.29 & 2.80 & 2.46 & 2.60 & 6 & 3.50 & 1.00 & 5.20 & 3.60 \\
\hline G & 9.32 & 9.34 & 9.25 & 9.34 & 7 & 9.10 & 9.00 & 9.00 & 8.70 \\
\hline H & 9.14 & 5.17 & 10.2 & 5.62 & 8 & 3.80 & 2.90 & 4.10 & 3.60 \\
\hline I & 4.25 & 1.62 & 1.72 & 1.97 & & & & & \\
\hline $\mathbf{J}$ & 9.14 & 8.93 & 9.03 & 9.25 & & & & & \\
\hline $\mathbf{K}$ & 2.22 & 2.76 & 2.26 & 2.74 & & & & & \\
\hline
\end{tabular}




\section{Types of losses and measures}

The losses during peanut digging were determined after the mechanized set passed. Two samples were collected per pass. The collected samples were spaced $20 \mathrm{~m}$ apart in longitudinal and lateral directions. A total of 20 samples were collected per treatment. The losses were measured by placing a $2 \mathrm{~m}^{2}(1,80 \mathrm{~m} \times 1,11 \mathrm{~m})$ frame transversely to the bed (windrow). All visible pods on the soil surface (VDL) inside the frame were collected. Then, the pods left inside the soil (up to $15 \mathrm{~cm}$ ) were collected, and thereby denoting invisible losses (IDL). The sum of the visible digging losses (VDL) and invisible digging losses (IDL) corresponded to the total digging losses (TDL) at each sample point.

The samples were sent to the Unesp/Jaboticabal Agricultural Machines and Mechanization Laboratory (LAMMA) in São Paulo, Brazil. The pods were weighed (for moisture) and then placed in an oven at $105{ }^{\circ} \mathrm{C}$ for $24 \mathrm{~h}$ until they exhibited a constant mass. After drying, the pods were weighed again and cleaned (mineral impurities were removed). The loss values were corrected to $8 \%$ of the water content and extrapolated to $\mathrm{kg} \mathrm{ha}^{-1}$.
Moreover, a simple analysis was performed to estimate the impact of losses for each condition (new and worn blades). It was assumed that the value of a dollar (USD) corresponded to R $\$ 3.15$ (February 2017). The cost of a peanut bag corresponded to R\$ 52.00 in the same month. Hence, the cost of a peanut bag in USD dollar was $\$ 16.50$ (25 kg).

\section{Data analysis}

The normality of the data was performed via the Shapiro-Wilk test, and a factorial $3 \times 2$ analysis of variance (ANOVA) was performed to test the main effects of blade condition and dig shift. Nonsignificant means were compared using the $\mathrm{F}$ test $(p \leq 0.05)$. When the test was significant, the effects were compared using the Tukey's test $(p \leq 0.05)$. Analyses were performed using Minitab software.

\section{RESULTS}

There were no statistically significant differences $(p>0.005)$ in treatments with visible losses (Figure 2). These results suggest that visible losses are not affected by blade conditions or digging shifts. In the extant studies, the VDL has

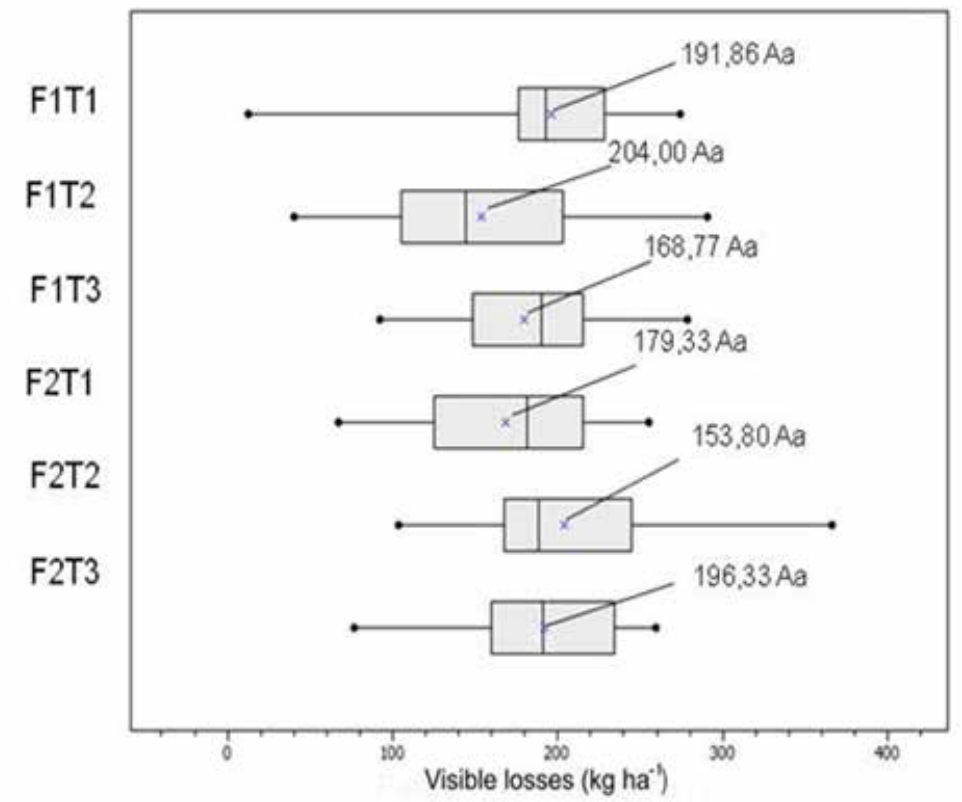

Figure 2. Visible losses (VDL) during peanut digging for three harvesting shifts $(\mathrm{T} 1=$ morning, $\mathrm{T} 2=$ afternoon, $\mathrm{T} 3=$ night $)$ and two blade conditions $(\mathrm{F} 1=$ new blade, $\mathrm{F} 2=$ blade used $)$ of the digging inverter. Uppercase denotes the effect of blade condition and lowercase denotes effect of time of the harvesting shift 


\section{CAN DIGGER BLADES WEAR AFFECT THE QUALITY OF PEANUT DIGGING?}

been related to mature pods and the amount of biomass that passes through the vibrating conveyor during the digging process (SANTOS et al., 2016), which in turn can reduce the VDL values when combined during operation.

Differences in the invisible losses (Figure 3) are observed when a new blade set is used in the digger. The use of new blades leads to a reduction in losses by approximately $4.5 \%$ of the yield. Conversely, when worn blades were used, the losses in relation to the yield were as high as $7 \%$. In addition to the condition of the blades, the shift time during which the harvest was conducted affected the indices of IDL in mechanized peanut digging. These results demonstrate the importance of periodic blade exchange and maintenance of the equipment used in peanut harvesting, which in turn can lead to a reduction in the amount of pod losses. Specifically, invisible losses can be reduced once the blades are used for cutting the soil slice (by shear stress) and consequently cutting peanut plants.

Despite these results, it is important to identify soil moisture and blade conditions that can lead to an increase in the invisible losses (IDL). Hence, independent of blade condition, when peanuts were dug in the afternoon, the IDL were lower when compared to those in the night shift. Furthermore, the losses in the night did not differ from those in the morning. The low IDL in the afternoon were because of soil moisture of approximately $23 \%$, while during morning and night shifts, the soil moisture was approximately $26 \%$, which deviated considerably from the recommended range of 18\%-20\% (SANTOS et al., 2010, ZERBATO et $a l ., 2017)$. Thus, this led to an increase in the IDL during morning and night shifts.

The existence of variability and differences between the conditions of the blades is shown in Figure 4, where the TDL is influenced by the digger blade condition. However, the effect of work shifts on the total losses in peanut harvesting was not significant. Thus, the results confirm that digging with used blades (used for up to $150 \mathrm{~h}$ ) increases the TDL. Hence, the blades should be changed. However, the accuracy of the results should be improved to determine the optimal time for changing the blades. Additionally, it is still a challenge for growers to determine the best time to change the blades. Unfortunately, in our study,

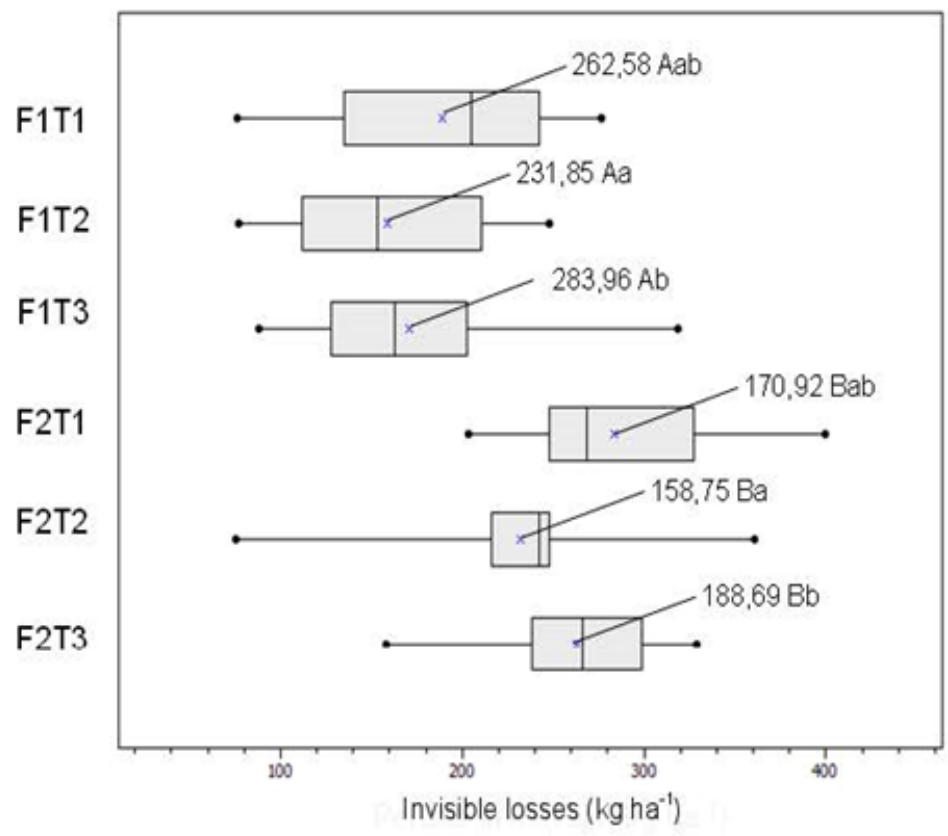

Figure 3. Invisible losses (IDL) during peanut digging for three harvesting shifts $(\mathrm{T} 1=$ morning, $\mathrm{T} 2=$ afternoon, $\mathrm{T} 3=$ night $)$ and two blade conditions $(\mathrm{F} 1=$ new blade, $\mathrm{F} 2=$ blade used $)$ of the digging inverter. Uppercase denotes the effect of blade condition and lowercase denotes the effect of shift time 


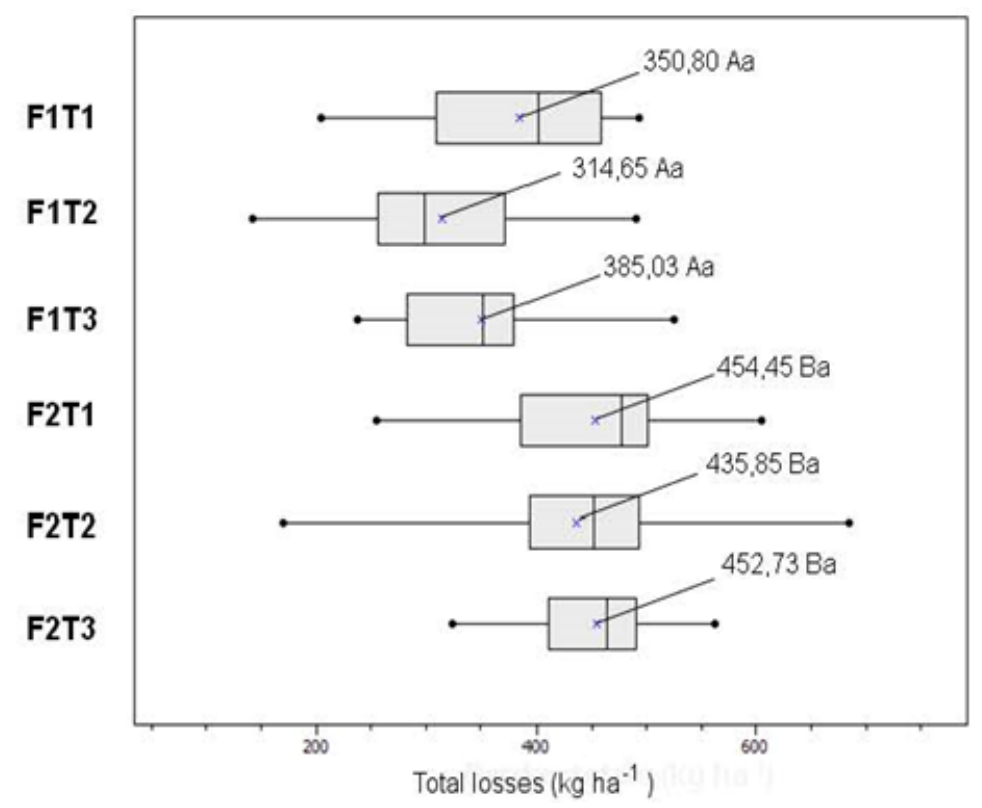

Figure 4. Boxes diagram for total losses (TDL) during peanut digging for three harvesting shifts $(\mathrm{T} 1=$ morning, $\mathrm{T} 2$ = afternoon, $\mathrm{T} 3$ = night $)$ and two blade conditions $(\mathrm{F} 1=$ new blade, $\mathrm{F} 2$ = blade used) of the digging inverter. Uppercase denotes the effect of blade condition and lowercase denotes the effect of shift time

we did not conduct multiple measurements after the operation was commenced. However, $8 \mathrm{~h}$ after the operation was commenced under loam soil conditions, the weight of the new blades reduced $3 \%$.

Although the shift time did not affect peanut digging, the growers should be cautious to digging peanuts at night. Once the vines of peanuts cover the soil surface, it is difficult to maintain the alignment of the longitudinal tractor axis with plant rows, especially in low visibility conditions. However, as per extant studies, the visibility problem can be solved by using an autopilot to guide the tractor during the day. However, in the extant studies, the autopilot was not examined for peanut digging at night.

A simple economic analysis showed an increase in economic loss by $21.77 \%$ when worn blades are used. When considering the total value of losses in the area harvested by each blade (12.5 ha), a reduction in total revenue of US\$2,413.13 was estimated because of losses with the use of old blades when compared to that obtained using new blades (Table 2). These results indicate that growers should pay close attention to the condition of blades during digging operations, and they should change the blades before the losses reach high levels, which in turn can compromise profit and yield.

\section{DISCUSSION}

Field conditions, such as soil moisture and soil type, are generally as the main factors in the wear of agricultural machines (OWSIAK, 1999). Thus, abrasive wear is indicated by $50 \%$ of the

Table 2. Economic analysis of total digging losses for peanut digging using new and used blades

\begin{tabular}{|c|c|c|c|c|c|}
\hline \multirow[t]{2}{*}{ Treatment } & \multicolumn{2}{|c|}{ TDL $^{*}$} & \multirow{2}{*}{$\frac{\text { Cost }}{\text { US } \$ h^{-1}}$} & \multirow{2}{*}{$\begin{array}{c}\text { Area } \\
\text { ha }\end{array}$} & \multirow{2}{*}{$\begin{array}{c}\text { Total } \\
\text { US } \$ \mathrm{ha}^{-1}\end{array}$} \\
\hline & $\mathrm{kg} \mathrm{ha}^{-1}$ & bags ha-1 & & & \\
\hline New Blades & $1,050.48$ & 42.02 & 693.33 & 12.50 & $8,666.62$ \\
\hline Used Blades & $1,343.03$ & 53.72 & 886.38 & 12.50 & $11,079.75$ \\
\hline
\end{tabular}

* TDL: Total Digging Losses. The values are considered by assuming the value of USD dollar as R\$ 3.15 and that of peanut bag as R\$52.00 in February 2017 
worn wear (MORAES, 2005). In peanut digging, it is impossible to avoid wearing of the blades. However, this can be mitigated by introducing a coating on the digging-shaker-inverter blades. This can attenuate abrasive wear in a manner similar to that in blades in sugarcane harvesters. Blades coated with tungsten or even solder have exhibited higher work times. This in turn reduces the loss of productivity and efficiency in sugarcane harvesting (VOLTARELLI et al., 2017).

Another factor that affects worn blades is their shape. This plays a significant role in the magnitude of the forces that are applied during digging (SHMULEVICH et al., 2007). It was determined that the forces applied on the blade were mainly concentrated on the knife in the lower part of the blade. Although we did not periodically measure the length and thickness of the blades during the experiment, the relationship between soil and blades is visible in the used peanut blade when compared to that in the new blade (Figure 1a). Specifically, this is evident for points 5 to 8 and $\mathrm{G}$ to $\mathrm{K}$ (Figure 1b). All of these points are in the lower part of the peanut blade, and these points are the first to enter the soil, thereby causing more wear.

The losses during peanut digging can be affected by other factors, such as the relationship between soil moisture and pod maturity, digger working depth, and soil type (INCE; GUZEL, 2003; ZERBATO et al., 2017). Nevertheless, neither of these factors affected our experiment when compared to the blade condition once the soil moisture and maturity were at the approximate recommended range, that is, $73 \%$ of soil maturity (ROWLAND et al., 2006) and 23\% of soil moisture (SANTOS et al., 2010).

With respect to digging peanuts during night shifts, the main problem corresponds to the rapid increase in soil moisture when the operation is conducted in a loam soil type, which cannot be controlled by growers. The other problem is related to the visibility to guide the mechanized set. A potential solution to this problem involves using an autopilot for sowing and digging. The use of an autopilot has led to reduction in losses (ORTIZ et al., 2013; SANTOS et al., 2016; SANTOS et al., 2019; ZERBATO et al., 2019). To date, no studies have reported the use of autopilot for peanut digging during night shifts. In our experiment, digging was performed during the night shift solely based on the experience of the tractor driver. This probably contributed to the highest loss values as per the facts mentioned earlier (alignment of the tractor and crop lines).

According to Giachini (2012), the losses in the night shift during sugarcane harvest can potentially be related to the operator's difficulty in seeing the crop lines. Noronha et al. (2011) showed nocturnal losses of $11.2 \%$ and diurnal losses of $9.3 \%$, and they concluded that the nocturnal losses should be $17 \%$ higher than the diurnal losses.

By considering that soil type affects losses during digging (Zerbato et al., 2017) and that TDL has a strong correlation with IDL (SANTOS et al., 2016), the values measured in this experiment can be considered as low. Specifically, the TDL values are $3.3 \%$ for new blades. Zerbato et al. (2017) reported TDL values in clayey soils as close to $4.4 \%$, and those in sandy and medium soils as $10.2 \%$ and $3.3 \%$, respectively. In future studies, we will investigate wear in different soil types and develop a method for using digital images to measure wear of the blades in the field.

\section{CONCLUSIONS}

- Mechanized harvesting of peanuts showed lower rates of invisible and total losses when conducted in the afternoon shift using a new blade. Furthermore, digging during the morning shift can increase losses.

- Additionally, visible losses are not affected by blade conditions or harvest time. When farmers use a set of new blades on the digging inverter, they can increase their profit by $22 \%$ by reducing the digging losses.

\section{ACKNOWLEDGMENTS}

The authors are grateful to the São Paulo State University (UNESP), Jaboticabal Campus for the academic support and availability of laboratories, and the National Council for Scientific and Technological Development (CNPq) for funding this project. 


\section{AUTHORSHIP CONTRIBUTION STATEMENT}

SANTOS, A.F.; OLIVEIRA, L.P.; OLIVEIRA, B.R.; ORMOND, A.T.S.: acquisition of data, analysis and interpretation of data, drafting and revising the work. SILVA, R.P.; SANTOS, A.F.: supervision and conception of the research, analysis and interpretation of data, drafting and revising the work.

\section{DECLARATION OF INTERESTS}

The authors declare that they have no known competing financial interests or personal relationships that could have appeared to influence the work reported in this paper.

\section{REFERENCES}

BINDER, M.; KLOCKE, F.; DOEBBELER, B. Abrasive wear behavior under metal cutting conditions. Wear, v. 376, p. 165-171, 2017.

BRAGACHINI, M.E.; PEIRETTI, J. Mejoras en la Eficiencia de Cosecha de Maní. Gacetilla de Prensa: 09/2008 - Marzo 2008. Disponível em: http://www.cosechaypostcosecha.org/data/ gacetillas/2008/20080319_mani.asp. Acesso em: 03 de junho de 2016.

CONAB. National Agriculture Company. Brasilian grains crop side dish. Brasília. Online at: https:// www.conab.gov.br/info-agro/safras/graos-2013

CONAB. National Agriculture Company. Brasilian grains crop side dish. Brasília. Online at: https:// www.conab.gov.br/info-agro/safras/graos-2018

EMBRAPA. Brasilian Enterprise of Agricultural Research. Brasilian system of soil classification. Brasília: Embrapa-SPI, Rio de Janeiro, 2013.

GIACHINI, C. F. Desempenho operacional de uma colhedora de cana-de-açucar (Saccarum spp.) em função dos turnos de trabalho. $57 \mathrm{f}$. Dissertação de Mestrado, Universidade Estadual Paulista, São Paulo, 2012.
INCE, A.; GUZEL, E. Effects of gynophore breaking resistance on losses in mechanized peanut harvesting. Proceedings of International Conference on Crop Harvesting and Processing, Louisville. ASAE Publication Number 701P1103e, ed. Graeme Quick, 2003.

MORAES, J. O. Abrasive Wear Resistance of Flexible Riser Protection Layers - Proposal of a New Test Methodology. 2005. 76 f. (Dissertação de Mestrado em Engenharia Mecânica) Universidade Federal de Uberlândia, Minas Gerais, 2005.

MOUAZEN, A. M.; NEMENYI, M. Tillage tool design by the finite element method: Part 1 . Finite element modelling of soil plastic behavior. Journal of Agricultural Engineering Research, v. 72, p. 37-51, 1999.

NORONHA, R. H. F.; SILVA, R.P.; CHIODEROLI, C. A.; SANTOS, E. P.; CASSIA, M. T. Statistical control applied in the process of mechanical sugar cane harvest in the diurnal and nocturnal periods. Bragantia, v. 70, p. 931-938, 2011.

ORTIZ, B. V.; BALKCOM, K. B.; DUZY, L.; VAN SANTEN, E.; HARTZOG, D. L. Evaluation of agronomic and economic benefits of using RTKGPS-based auto-steer guidance systems for peanut digging operations. Precision Agriculture, v. 14, p. $357-375,2013$.

OWSIAK, Z. Wear of spring tine cultivator points in sandy loam and light clay soils in southern Poland. Soil and Tillage Research, v. 50, p. 333340, 1999.

PEEL, M.; FINLAYSON, B.; MCMAHON, T. Updated world map of the Koppen-Geiger climate classification. Hydrology Earth and System Sciences, Kattenburg - Lindau, v. 11, p. 16331644, 2007.

ROSA, U. A.; WULFSOHN, D. Constitutive model for high-speed tillage using narrow tools. Journal of Terramechanics, v. 36, p, 221-234, 1999.

ROWLAND, D.L.; SORENSEN, R.B.; BUTTS, C.L.; FAIRCLOTH, W.H. Determination of maturity and degree day indices and their success in predicting peanut maturity. Peanut Science, v. 33, p. 125-136, 2006. 
SANTOS, A. F.; KAZAMA, E. H.; ORMOND, A. T. S.; TAVARES, T. O.; SILVA, R. P. Quality of mechanized peanut digging in function of the auto-guidance. African Journal of Agricultural Research, v. 11, p. 4894-4901, 2016.

SANTOS, A.; SILVA, R.P.; ZERBATO, C.; MENEZES, P.C.; KAZAMA, E.H.; PAIXÃO, C.S.S.; VOLTARELLI, M.A. Use of real-time extend GNSS for planting and inverting peanuts. Precision Agriculture, v. 20, p. 840-856, 2019.

SANTOS, E. P.; SILVA, R. P.; FURLANI, C. E. A.; BERTONHA, R. S.; \& MEDEIROS; R. S. Peanut losses in the mechanized harvesting. Proceedings of Congreso Latinoamericano y del Caribe de Ingeniería Agrícola, 2010.

SHMULEVICH, I.; ASAF, Z.; RUBINSTEIN, D. Interaction between soil and a wide cutting blade using the discrete element method. Soil and Tillage Research, v. 97, p. 37-50, 2007.

SILVA, R. P.; MAHL, D. Peanut losses in the mechanized harvesting crop 2007/2008. Rural Engineering Department. São Paulo State University. Jaboticabal, SP, Brazil, 2008.

SILVA, R. P.; SANTOS, A. F.; CARREGA, W. S. Avanços na produção de amendoim. Jaboticabal: FUNEP, 2019.
USDA - United States Department of Agriculture https://apps.fas.usda.gov/psdonline/reportHandler. ash $x$ ?fileName $=$ BVS\&reportId $=918 \&$ templateId $=$ $1 \&$ format $=\mathrm{html}$ Accessed 24 November 2020.

VOLTARELLI, M. A.; SILVA, R. P.; CASSIA, M. T.; DALOIA, J. G. M.; PAIXÃO, C. S. S. Quality of basal cutting in sugarcane using blades of different coating and angles. Revista Ciência Agronômica, v. 48, p. 438-447, 2017.

WILLIAMS, E. J.; DREXLER, J. S. A nondestructive method for determining peanut pod maturity. Peanut Science, Tifton, v. 8, p. 134-141, 1981.

ZERBATO C.; FURLANI, C. E. A.; SILVA, R. P.; VOLTARELLI, M. A.; SANTOS, A. F. Statistical control of processes applied for peanut mechanical digging in soil textural classes. Engenharia Agrícola, Jaboticabal, v. 37, p. 315-322, 2017.

ZERBATO, C.; FURLANI, C. E.; OLIVEIRA, M. F. D.; VOLTARELLI, M. A.; TAVARES, T. O.; CARNEIRO, F. M. Qualidade da semeadura e do arranquio mecanizados de amendoim com uso do piloto automático. Revista Brasileira de Engenharia Agrícola e Ambiental, v. 23, p. 630637, 2019. 